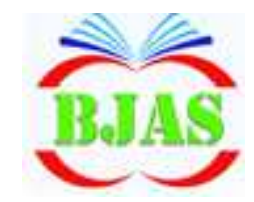

Available online at http://journal.bajas.edu.iq

College of Agriculture, University of Basrah

DOi:10.21276/basjas

\section{Basrah Journal \\ of Agricultural \\ Sciences}

ISSN 1814 - 5868 Basrah J. Agric. Sci., 32(1): 15-24, 2019

E-ISSN: 2520-0860

\title{
Comparison Study between the Field Performance of a Movable Boards and Conventional Ditch Openers in Cultivated and Uncultivated Soils, Part 3: The Specific Resistance
}

\author{
Shaker H. Aday*\&Yarub Al-muthafar \\ Department of Machines and Equipment, College of Agriculture, University of \\ Basrah, Iraq \\ *Corresponding author e-mail: shaker.h.1953@gmail.com \\ Received 21 Feb 2019; Accepted 14 March 2019; Available online 15 March 2019
}

\begin{abstract}
The field performance of movable boards ditch opener (MB) and conventional ditch opener (CD) was contrasted by using a specific resistance to determine the optimum performance of either one of them. The comparison was conducted using three operating depths $(30,40$ and $50 \mathrm{~cm})$, three angles between the boards of $\mathrm{MB}\left(45,60\right.$ and $\left.75^{\circ}\right)$, one angle for $\mathrm{CD}\left(65^{\circ}\right)$ because its boards were fixed, three wings width of the foot of $M B$ whereas, for $C D$, one share width $(35 \mathrm{~cm})$ and two soil types (cultivated and uncultivated). CD could not penetrate the uncultivated soil more than $25 \mathrm{~cm}$ so that there was one operating depth. The results of the experiments showed that SR for MB decreased as the operating depth, the angle between the boards and the width of the wings of the foot in both soil types were increased. Specific resistance (SR) for $\mathrm{CD}$ also decreased as the operating depth increased in the cultivated soil, but in the uncultivated soil, $C D$ could not penetrate the soil more than $25 \mathrm{~cm}$. SR for MB was lower than that for $C D$ for all operating depths, the angle between the boards, the width of the wings of the foot in both soil types. SR for $\mathrm{MB}$ and $\mathrm{CD}$ in the cultivated soil was low compared to uncultivated soil. The soil type decreased SR for MB more than the operating depth, the angle between its boards and the width of its wings. On the other hand, the angle between its boards reduced SR more than the width of the wings and the operating depth. $\mathrm{MB}$ surpassed $\mathrm{CD}$ in giving lower $\mathrm{SR}$ and that means the field performance of $\mathrm{MB}$ was higher than that for $\mathrm{CD}$.
\end{abstract}

Keywords: Conventional ditch opener, Movable boards ditch opener, Specific resistance, Operating depth, Angle between movable boards.

\section{Introduction}

The specific resistance (SR) is widely used to evaluate the performance of agricultural machines. SR is the draft force divided by the cross-section area. Thus SR depends upon the rate at which the draft force increases relative to that of the cross-section area (A) (Aday, 2015; Aday et al., 2016; Aday \& AlMuthafer, 2018). When the draft force increased by a greater rate compared with the disturbed area (DA), SR increased and the 
controversy occurred when the rate of increase in DA was greater than that for the draft force. Thus as the value of SR is low the performance of the machine is high. This means the machine spends less draft force to disturb one meter of soil (Ahmed \& Godwin, 1983; Godwin et al., 1984).

SR for the conventional ditch opener (CD) which was provided with big and fixed boards, it was very high especially when the soil was uncultivated, hard (dry soil) and having compacted (Aday \& Al-Muthafar, 2018). In addition to that, the implement share could not penetrate the soil easily because it was wide and was not provided with a sharp point to break through the soil layers. It also produces the same cross-section width ditches and that would not preferable in the field where different cross-section width ditches are required. Moreover, CD suffers also from high draft force requirement and SR. For these reasons a movable boards ditch opener (MB) was designed to elements these problems or at least reduces them as well as reduces the specific resistance.

The literature showed that SR decreased as the operating depth increased for conventional subsoiler as well as for the modified subsoiler which was provided with two shallow tines to disturb the soil of the top layers whereas, the subsoiler disturbs the deep layers (Spoor \& Godwin, 1978; Owen, 1988; Mckyes \& Masware, 1997). The winds enlarge the area of disturbed soil through creating cracks in the soil which develops from its outer edges toward the soil surface. The soil types have also a great effect on SR of the implement, it is lower in the cultivated soil compared with uncultivated soil (Reeder et al., 1993; Aday \& Al-Haliphy, 2001; Aday \& Hilal, 2004). SR values depend on the soil moisture content, it increases considerably in the hard and plastic states (Aday et al., 2011; Ramadan, 2011; Godwin \& Spoor, 1977).

\section{Materials and Methods:}

$\mathrm{CD}$ consists of a frame, two boards and a wide share. The boards were fixed on the frame their edges were sharp to cut the sides of the ditches made by the machine (Fig. 1 . MB) consists of a frame made of steel to withstand the stress imposed by the soil on the implement and subsoiler. The subsoiler consists of the leg (shank) and foot fix at its lower end of the leg, (Fig. 2a). The forward inclination angle (rake angle) of the leg is $60^{\circ}$. The foot was provided with wings to widen the ditch floor. The inclination angle of the wings relative to the horizontal line was $30^{\circ}$. The attack angle of the foot front was $25^{\circ}$ to facilitate the soil penetration by the implement. The subsoiler was fixed tightly to the frame. MB was provided with two boards. The length and width of each board are 1.0 and $75 \mathrm{~cm}$ respectively. A steel shaft of $25 \mathrm{~mm}$ diameter was fixed behind the leg, (Fig. 2b). The two boards were fixed behind the shaft by hinges. The hinges enable the two boards to move freely in two directions as shown below to obtain different angles between them and that enables the implement to form different cross-section width ditches. The two boards were provided with a telescopic bar fixed between them to obtain the required angle. The lower edges of the two boards made an angle of $45^{\circ}$ with soil surface to prevent them from skidding on the soil surface. The top edge of one board was provided with a support bar fixed to the implement frame to prevent the side movement of both boards when the two boards exposed to unequal lateral force. The support bar position can be changed according to the angle between the two board 


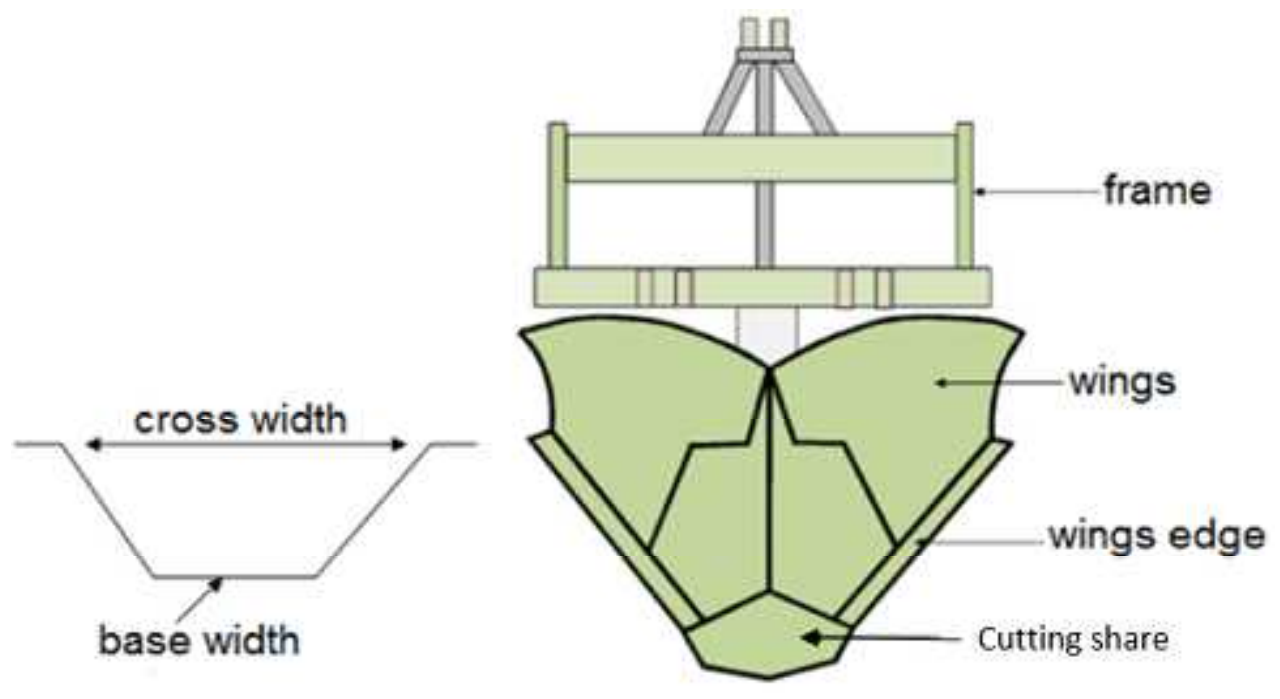

Fig. (1): The conventional ditch opener.

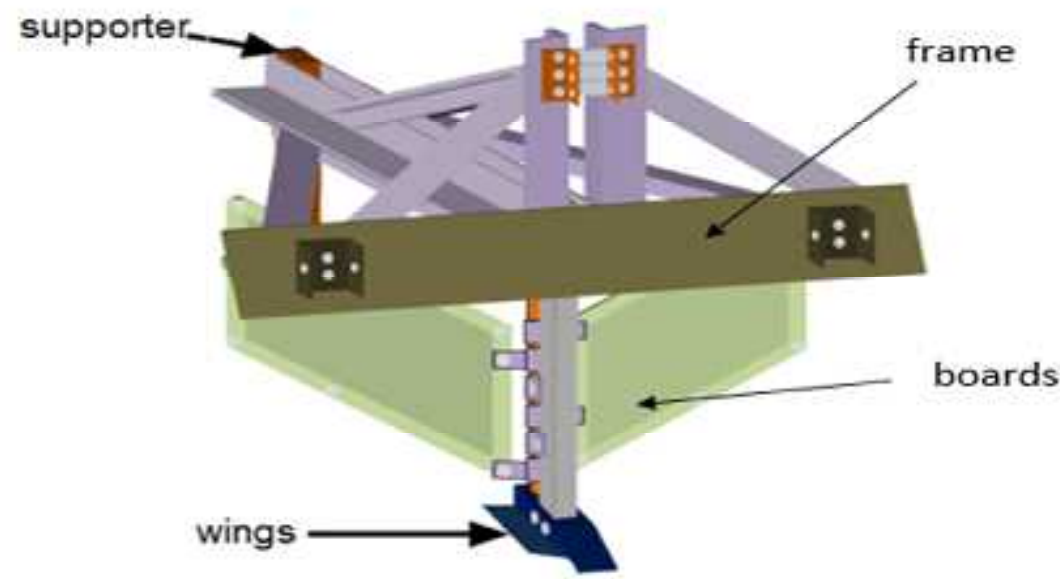

Fig. (2): The movable board's ditch opener and the foot with the wings. (A): Geometrical view

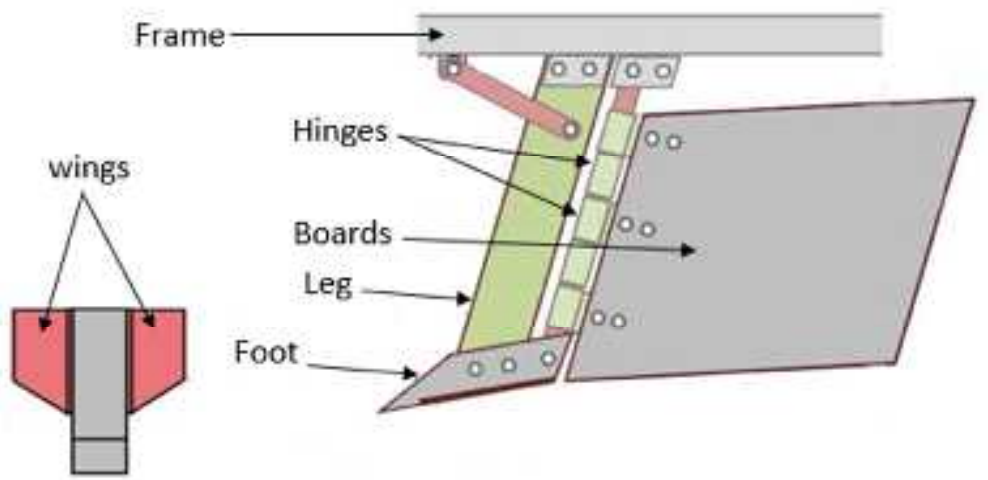

(B): Side view. 
because the frame was provided with many holes.

\section{The measurement of the soil properties}

The soil bulk density and the moisture content were measured by methods described in Black et al. (1983; table 1). The soil strength parameters, cohesion internal friction angle, and the soil penetration index were measured by the Annual ring and the penetrometer tool using the methods described by Gill \& Vandenberg (1968). These parameters were measured for the uncultivated and cultivated soils. The results are shown in the table (1).

Table (1): Soil physical properties for cultivated and uncultivated soils.

\begin{tabular}{|c||c|c|c||c|c|c||}
\hline \multicolumn{1}{|c||}{} & \multicolumn{3}{c||}{ Cultivated soil } & \multicolumn{3}{c||}{ Uncultivated soil } \\
\cline { 2 - 7 } $\begin{array}{c}\text { depth } \\
(\mathrm{cm})\end{array}$ & $\begin{array}{c}\text { Bulk density } \\
\left(\mathrm{kg} \mathrm{m}^{-3}\right)\end{array}$ & $\begin{array}{c}\text { Cone } \\
\text { index } \\
\left(\mathrm{kN} \mathrm{m}^{-2}\right)\end{array}$ & $\begin{array}{c}\text { M.C } \\
(\%)\end{array}$ & $\begin{array}{c}\text { Bulk } \\
\text { density } \\
\left(\mathrm{kg} \mathrm{m}^{-3}\right)\end{array}$ & $\begin{array}{c}\text { Cone } \\
\text { index } \\
\left(\mathrm{kN} \mathrm{m}^{-2}\right)\end{array}$ & $\begin{array}{c}\text { M.C } \\
(\%)\end{array}$ \\
\hline $0-10$ & 1266 & 1713.2 & 23.8 & 1458 & 3115.0 & 9.25 \\
\hline $10-20$ & 1150 & 1495.2 & 26.65 & 1449 & 3893.8 & 13.20 \\
\hline $20-30$ & 1367 & 2803.5 & 24.7 & 1417 & 3166.7 & 16.61 \\
\hline $30-40$ & 1240 & 2118.2 & 30.61 & 1272 & 2219.4 & 24.77 \\
\hline $40-50$ & 1141 & 1869.0 & 33.30 & 1161 & 1619.8 & 30.33 \\
\hline
\end{tabular}

Table (2): Soil mechanical properties.

\begin{tabular}{|c|c|c|c|c|c|c|c|}
\hline \multirow{2}{*}{$\begin{array}{l}\text { Soil } \\
\text { types }\end{array}$} & \multirow{2}{*}{$\begin{array}{c}\text { Cohesion } \\
\mathrm{C} \\
\left(\mathrm{kN} \mathrm{m}^{-2}\right)\end{array}$} & \multirow{2}{*}{$\begin{array}{c}\text { Angle of } \\
\text { Internal } \\
\text { friction } \\
\varnothing \\
\text { (Degrees) }\end{array}$} & \multicolumn{3}{|c|}{ Soil texture } & \multicolumn{2}{|c|}{ Consistency } \\
\hline & & & Sand & Silt & Clay & P.L. & L.L. \\
\hline cultivated & 9.48 & 40.09 & \multirow{2}{*}{4.2} & \multirow{2}{*}{44.2} & \multirow{2}{*}{51.6} & \multirow{2}{*}{28} & \multirow{2}{*}{46} \\
\hline uncultivated & 6.83 & 34.37 & & & & & \\
\hline
\end{tabular}

\section{The experiments parameters}

$\mathrm{CD}$ and $\mathrm{MB}$ were tested in the field using three operating depths $(30,40$ and $50 \mathrm{~cm}$ ), three angles between the movable boards of $\operatorname{MB}\left(45,60\right.$ and $\left.75^{\circ}\right)$ and three wings widths $(25,35$ and $45 \mathrm{~cm})$ for $\mathrm{MB}$ and $35 \mathrm{~cm}$ for $\mathrm{CD}$ (constant share width). The experiments were carried out in uncultivated and cultivated soils because it was provided with share. CD operating depth in the uncultivated soil was $25 \mathrm{~cm}$ only because it could not penetrate the soil more than this depth. The angle between the boards of $\mathrm{CD}$ was constant $\left(65^{\circ}\right)$ because its boards were fixed on the frame of the implement. The soil texture was silty clay (table 2). 


\section{The draft force measurement}

The draft force of $\mathrm{CD}$ and $\mathrm{MB}$ were measured using hydraulic dynamometer. Both implements were sequentially attached to a tractor. The tractor- implement combination was towed by another tractor using flexible cable. The hydraulic dynamometer was attached to the towing tractor from one end and to the flexible cable from the other end. The operating depth was determined in advance and the towing tractor put in gear while the gearbox of the towed tractor left in neutral. The towing tractor was left to move at least three meters to approach the maximum speed then the readings were recorded from the dynamometer. The tractorimplement combination was left to move a distance of $15 \mathrm{~m}$. The run was repeated three times in different position within the field of the experiments. The same runs were repeated for the other operating depths and angle between the movable boards in both soil types.

The draft force was calculated using the equation (1)

$$
\mathrm{F}=0.88+\mathrm{A} . \mathrm{X}
$$

Where:

$\mathrm{F}=\mathrm{draft}$ force $(\mathrm{kN})$

$\mathrm{X}=$ the dynamometer readings $\left(\mathrm{kN} \mathrm{m}^{-2}\right)$

$\mathrm{A}=$ Cross-section area of the hydraulic cylinder $\left(0.0044156 \mathrm{~m}^{2}\right)$

\section{Measurement of the disturbed area.}

The cross-section area for $\mathrm{CD}$ and $\mathrm{MB}$ were measured in the field for all operating depths, angles between the boards in both soil types. The soil of the cross-section area was dogged out by hand to keep the ditch sides undisturbed. The widths of the cross-section of the ditch at the soil surface and bottom were measured. The ditch depth was also measured. The measurements were repeated for three positions for each run (Fig. 3). The cross-section area of the ditch was calculated using the equation. (2).

$$
A=2\left[\frac{1}{2} \frac{(b-W i)}{2} d\right]+d \cdot W i=\frac{(b+W i) d}{2}
$$

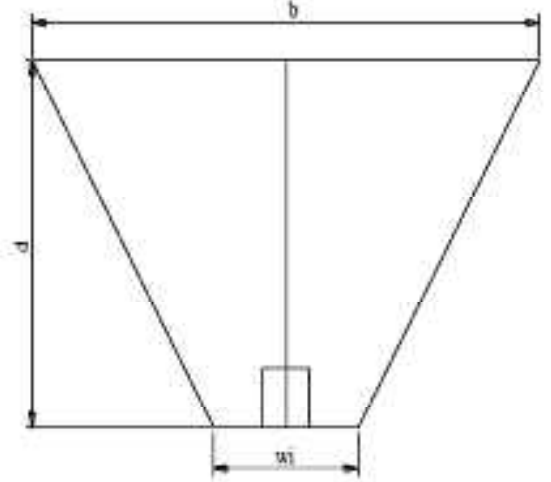

(2)

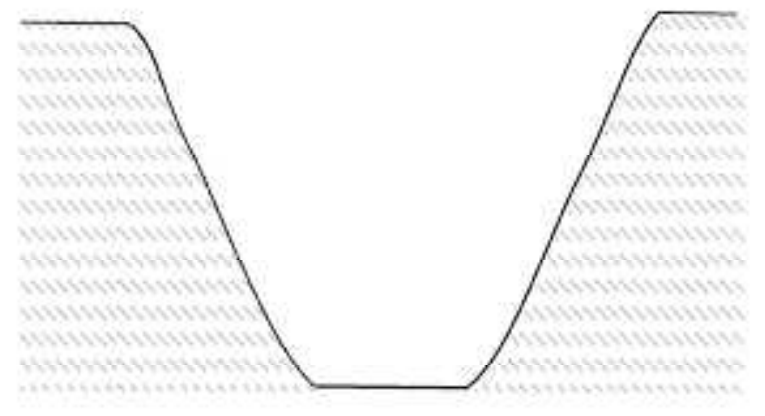

(1)

Fig. (3): The dimensions of the ditch produced by MB and CD.

\section{Results \& Discussion}

The effect of the operating depth of the implement and the soil types on the specific resistance of $\mathrm{CD}$ and $\mathrm{MB}$
The effect of the operating depth and the soil types on SR of CD and MB is shown in Fig. (4). It decreased appreciably as the operating depth increased for $\mathrm{CD}$ and $\mathrm{MB}$ in both soil 
types. In the cultivated soil where both implements penetrated the soil easily to the required depths, SR for $\mathrm{CD}$ decreased from 177.98 to $123.21 \mathrm{kNm}^{-2}$ (31\%) whereas, for $\mathrm{MB}$, it decreased from 105.99 to $86.68 \mathrm{kNm}^{-2}$ $(18 \%)$ when the operating depth increased from 30 to $50 \mathrm{~cm}$. In the uncultivated soil, the $\mathrm{CD}$ could not penetrate the soil more than $25 \mathrm{~cm}$ because of its wider share and boards while MB penetrated the soil easily to the required depths. SR for CD was $240.40 \mathrm{kNm}^{-}$ 2 whereas for MB decreased from 135.27 to $115.91 \mathrm{kNm}^{-2}(14 \%)$ when the operating depth increased from 30 to $50 \mathrm{~cm}$. The reduction in $\mathrm{SR}$ is related to that the rate of increase in the draft force due to the operating depth was lower than that in DA for both implements.

Comparing SR of CD and that of MB, SR for $\mathrm{MB}$ was lower than that for $\mathrm{CD}$ for all depths tested but the difference between their values decreased with operating depth. For example, for operating depth of $30 \mathrm{~cm}$ in the cultivated soil, SR for CD was $177.98 \mathrm{kNm}^{-2}$ while for $\mathrm{MB}$ was $105.99 \mathrm{kNm}^{-2}$ (lower by $40 \%$ ), for operating depth of $50 \mathrm{~cm}$, SR for $\mathrm{CD}$ was $123.21 \mathrm{kNm}^{-2}$ whereas for $\mathrm{MB}$ was $86.68 \mathrm{kNm}^{-2}$ (lower by $30 \%$ ). In the uncultivated soil, there was a big difference between their SR and that was because CD could not penetrate the soil more than $25 \mathrm{~cm}$ due to its high resistance because of its hardness. In addition to that the leg of MB subsoiler disturbed the soil first and then the boards dogged it out of the ditch and this sort of operation required less draft force, whereas, for $\mathrm{CD}$ its boards cut the soil with share and digging it out at the same time and that required more force.

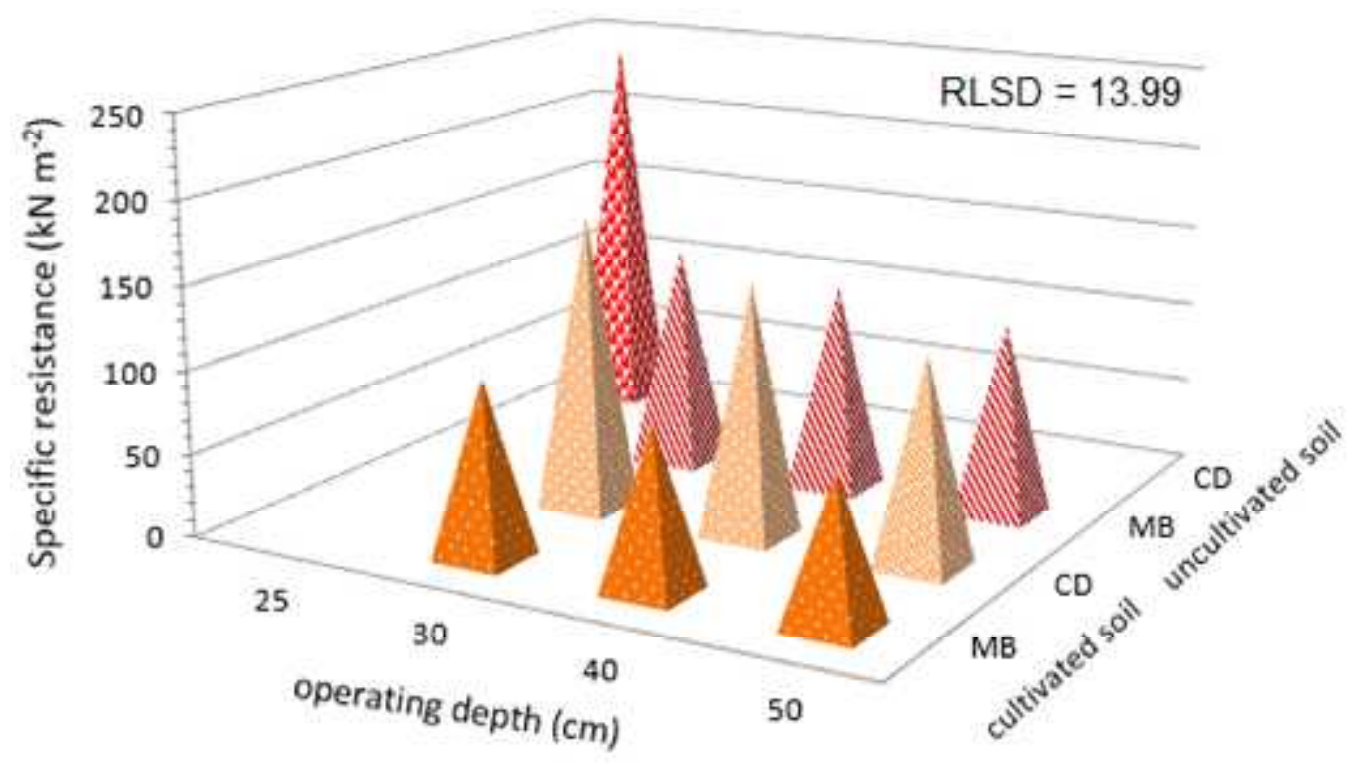

Fig. (4): The relationship between the specific resistance of MB and CD and the operating depths in the cultivated and uncultivated soils

The effect of the operating depth of the implement and the angle between the movable boards of the implement on the specific resistance of $C D$ and $M B$

SR for MB decreased with increasing the operating depth and angle between its boards except for angle $45^{\circ}$. While, SR increased by little amount with operating depth, as shown 
in Fig. (5). This increase can be related to that the angle between the two boards was so small that their ends could not cut the ditch sides which resulted in narrow cross-section ditches, while, the

angles of 60 and $75^{\circ}$ cut the ditch sides which widen the cross-section of the ditches further and that resulted in lower SR. For CD which the angle between its boards was constant $\left(65^{\circ}\right)$, SR was higher than that for MB except for operating depth of $50 \mathrm{~cm}$ where the controversy occurred and that was because the operating depth of $\mathrm{MB}$ was $50 \mathrm{~cm}$, whereas for $\mathrm{CD}$ was $25 \mathrm{~cm}$ only (half of that for $\mathrm{MB}$ ).

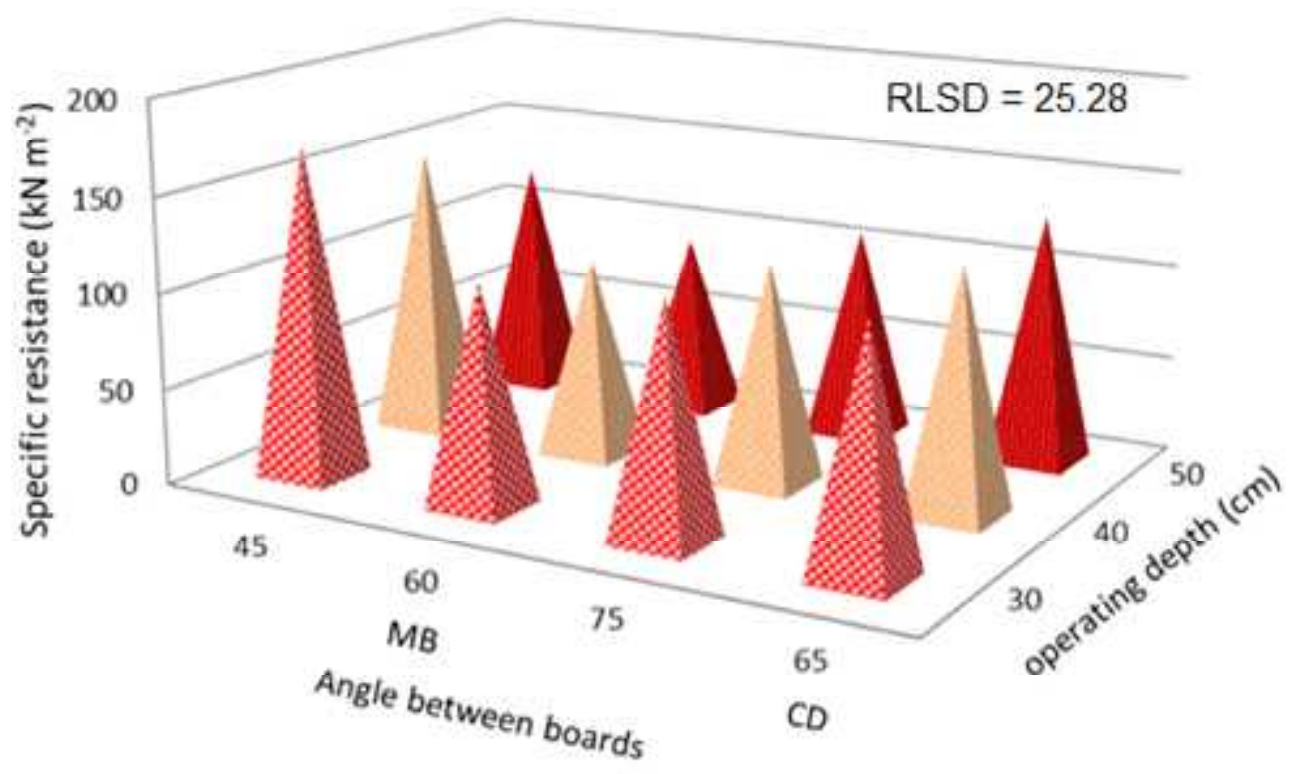

Fig. (5): The relationship the specific resistance of $M B$ and $C D$ and the operating depths for different angles between the boards.

The effect of the soil types and the angles between the boards on the specific resistance of $\mathrm{CD}$ and $\mathrm{MB}$

SR for MB decreased considerably as the angle between the boards increased in both soil types. However, the rate of reduction was higher in the cultivated soil compared to uncultivated soil (Fig. 6). In the uncultivated soil, the increases in DA was limited, where it was higher than the draft force by a little amount. This is because the soil resistance was high which the implement spent the majority of its power in overcoming this resistance instead of disturbing greater volume of soil. Furthermore, the edges of the boards cut slices of soil from both sides of the ditch and that required extra draft force whereas, the increase in DA due to these soil slices was limited. However, in the cultivated soil the resistance was lower so that the draft force requirement was not high whereas, DA was high which resulted in lower SR.

For MB, SR was lower than that for CD for all angles between its boards in both soil types. The results showed that the differences between the values of SR of MB and that of $\mathrm{CD}$ increased as the angle between the boards of MB increased. In the cultivated soil, SR for $\mathrm{CD}$ was $148.6 \mathrm{kN} / \mathrm{m}^{2}$ while for $\mathrm{MB}$ at an angle of $45^{\circ}$ was $117.09 \mathrm{kNm}^{-2}$ (lower by $21 \%$ ), increasing the angle of $\mathrm{MB}$ to $75^{\circ}$ the value of SR decreased to $91.82 \mathrm{kNm}^{-2}$ (lower by $38 \%$ ). Whereas, In the uncultivated soil, SR for CD was $240.40 \mathrm{kNm}^{-2}$ while for MB the values for both above angles were 143.12 $\mathrm{kNm}^{-2}$ (lower by $40 \%$ ) and $116.67 \mathrm{kNm}^{-2}$ (lower by $40 \%$ and $51 \%$ ) respectively. This means $\mathrm{MB}$ supervision to $\mathrm{CD}$ in giving lower SR values. 
The effect of the operating depth and the width of the wings on $M B$ and $C D$ specific resistance

SR for MB decreased as the foot width increased for all the operating depths (Fig. 7). However, the width of the wing was more effective on SR as the operating depth increased. For example, at the operating depth of $30 \mathrm{~cm}$, SR for MB decreased from 128.20 to $117 \mathrm{kNm}^{-2}(8.7 \%)$, when the wings width increased from 25 to $45 \mathrm{~cm}$. Whereas, for operating depth of $50 \mathrm{~cm}$, SR decreased from 118.6 to $102.6 \mathrm{kNm}^{-2}(13.5 \%)$ and that was because the wider wings increased the width of the ditch base (floor) as well as with the deeper operating depth the number of cracks created in the soil by wider wings developed sideways and then upward which resulted in greater cross-section width ditch and that reduced SR (Aday \& Hmood 1995; Aday \& Hilal 2001).

However, SR for CD (the share width was constant at $35 \mathrm{~cm}$ ) was higher than that for MB for all wings widths. This was because the wide share of $C D$ could not penetrate the soil easily due to the high resistance on it so that it required more force to penetrate the soil and that negatively affected SR.

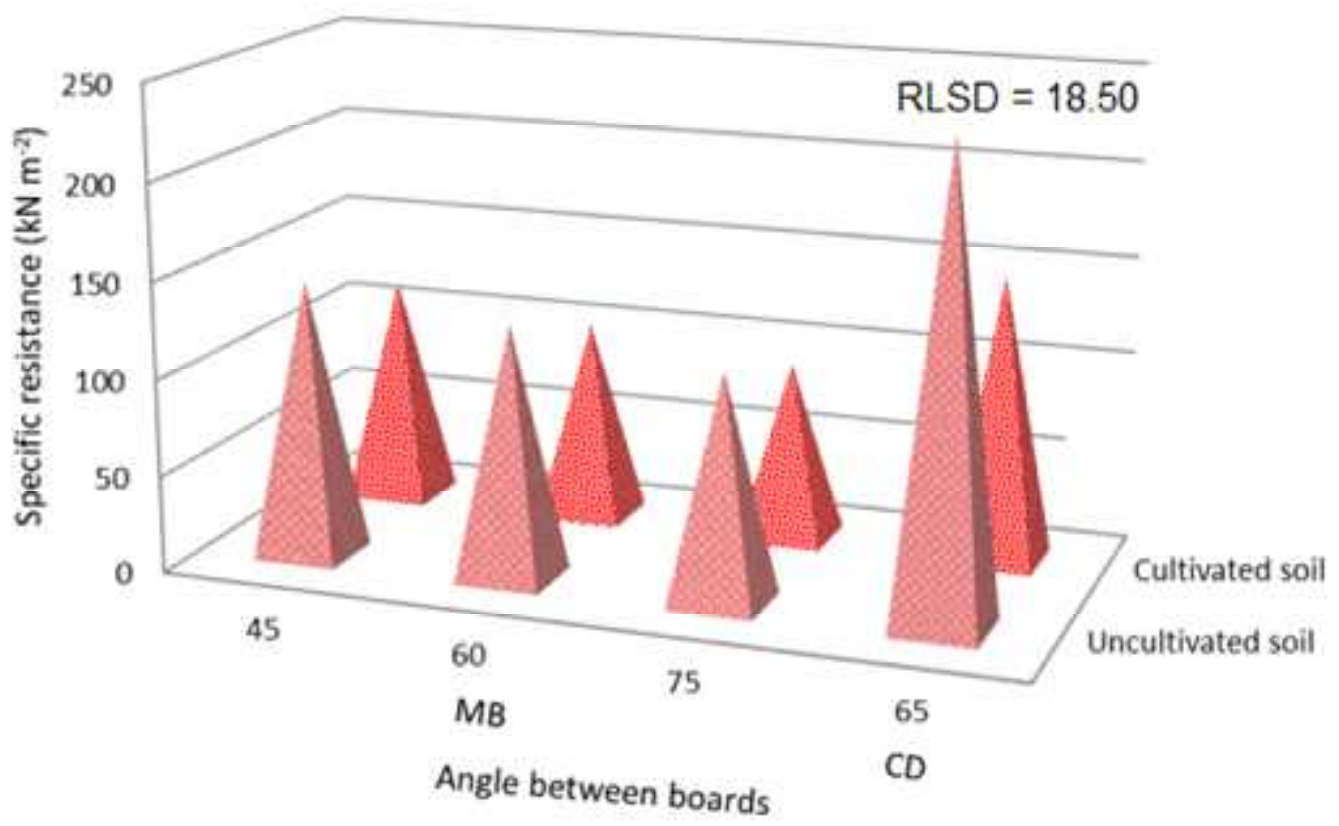

Fig. (6): The relationship between the specific resistance of $M B$ and $C D$ and the angle between the boards of MB in the cultivated and uncultivated soils

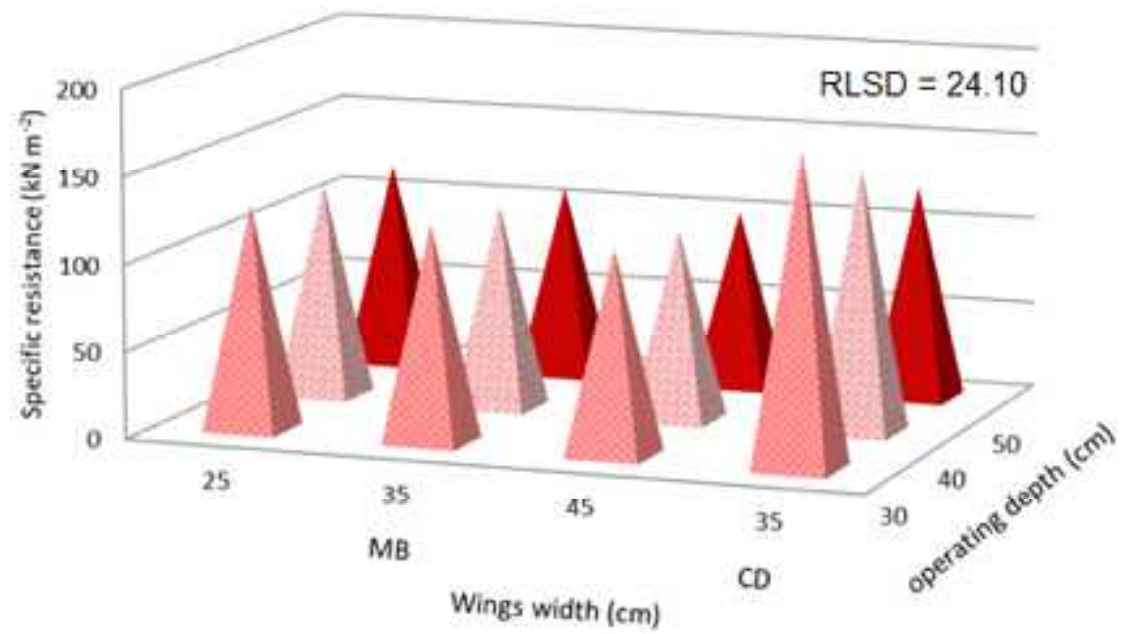




\section{Fig. (7): The relationship between the specific resistance of $M B$ and $C D$ and the operating depth for different wings widths}

\section{Conclusion}

The following conclusions can be drawn from the results:

1-SR for MB decreased as the operating depth, the angle between the boards and the width of the wings of the foot increased in both soil types.

2-SR for CD decreased as the operating depth increased in the cultivated soil, whereas, in the uncultivated soil $\mathrm{CD}$ could not penetrate the soil more than $25 \mathrm{~cm}$.

3-SR for MB was lower than that for $\mathrm{CD}$ for all operating depths, the angle between the boards, the width of the wings in both soil types.

4-SR for $M B$ and $C D$ was lower in the cultivated soil compared with uncultivated soil.

5-The soil type surpassed the operating depth, the angle between its boards and the width of its wings in reducing SR of MB. Whereas, the angle between its boards reduced SR more than the width of the wings and the operating depth.

\section{Acknowledgement}

The authors are highly indebting to Mr Dhia'a S. Ashoor the lecturer in The Department of Machines and Equipment, College of Agriculture, the University of Basrah for technical assistance of the early draft of the manuscript.

\section{References}

Aday, S.H. (2015). Theory of agriculture machines. Alghadeer Co. for Printing and Publishing Ltd. Basrah, Iraq. 154pp.

Aday, S.H. \& Al-Haliphy, A.R. (2001). The disturbed area and the specific resistance of a modified subsoiler in heavy soil. Basrah J. Agric. Sci., 14 (3): 73-98.
Aday, S.H. \& Al-Muthafar, Y.W. (2018). Comparison between the performance of a movable boards ditch opener and the conventional ditch opener in cultivated and uncultivated soil. Part (1): The draft force. Basrah J. Agric. Sci., 31(1): 85-92

Aday, S.H. \& Hilal, Y.Y. (2004). The effect of lifting angle of the subsoiler foot wings on its field performance in heavy soils. The draft force and the disturbed area. Iraq $\mathrm{J}$. Agric., 9(3): 195-207.

Aday, S.H. \& Hilal, Y.Y. (2001). The effect of wings width on the field performance in heavy soils. The specific resistance and energy utilization efficiency. Basrah J. Agric. Sci., 14(1): 51-66.

Aday, S.H. \& Hmood, M.S. (1995). The field performance of the subsoiler when provided with wings and shallow tines in heavy soils. Mesopotamia J., 7(4): 16-20.

Aday, S.H.; Abdul-Nabi, M.A. \& Ndawii, D.R. (2011). The effect of the lateral distance between the shallow tines on the disturbed area and the specific resistance of the subsoiler. Part (2).

Aday, S.H.; Ramdhan, M. \& Ali, H. (2016). Evaluation of the field performance of partially swerved double tines subsoiler in two different soil textures and two levels of moisture contents. Part 2: Specific resistance and energy utilization efficiency. 2nd national conference on mechanization and new technology, Ramin University of Agricultural Science and Natural Resources. Ahvaz, Khuzestan, Iran, June.: 1-14.

Ahmed, M.H. and Godwin, R.J. (1983) The influence of wing position on subsoiler penetration and soil disturbance. J. Agric. Engng. Res. 28: 489-492.

Black, C.; White, J.L.; Ensminger, J.E \& Clark, F.E. (1983). Method of soil analysis. $6^{\text {th }}$ edition. Am. Soc. Agron, Madison. Wisconsin: 770pp.

Gill, W.R. \& Vandenberg, G. E. (1968). Soil dynamic in tillage and traction. Agriculture 
handbook, No. 316 Agric. Res. Service, U.S.D.A.

Godwin, R.J. \& Spoor, G. (1977). Soil failure with narrow tines. J. Agric. Eng. Res., 22: 213-228.

Godwin, R.J; Spoor, G. \& Soomro, M.S. (1984). The effect of tine arrangement on soil forces and disturbance. J Agric. Eng. Res; 30; 47-56.

Mckyes, E. \& Masware, J. (1997). Effect of design parameters of flat tillage tools on loosening of clay soil. J. Soil \& Tillage Res., 43: 195-204.

Owen, G.T. (1988). Soil disturbance associated with deep subsoiling in compact soils. Can. Agric. Eng., 30 (1): 33-37.
Ramadan, M.N. (2011). Evaluation of the mechanical performance of the double tines longitudinally arranged subsoiler and its effect on some growth characteristic of barley crop. M. Sc. Thesis. Coll. Agriculture, Univ. Basrah: 174pp.

Reeder, R.L.; Wood, R.K. and Finck, C.L. (1993). Five subsoiler designs and their effects on soil properties and crop yields. Trans ASAE, 36 (6): 1525-1531.

Spoor, G. \& Godwin, R.G. (1978). An experimental investigation into the deep loosening of soil by rigid tines. J. Agric. Eng. Res., 23 (3): 243-258. 